\title{
Identity Politics, Democratisation and State Building in Ethiopia's Federal Arrangement
}

\section{Kidane Mengisteab}

\section{Abstract}

Relations between identity politics, democratisation, and state building are complex, especially in the cases of relatively young post-colonial countries, such as those in Sub-Saharan Africa. The complexity emanates, in part, from the multiplicity of the intervening variables. This paper proposes that the factors that impinge on the relationships include: the nature of the historical state-identity and inter-identity relations, the nature of the state, including the quality of its leadership and its effectiveness in promoting the well-being of its citizens equitably, the state's approach to state-building, the organisation of political parties, and the structure of electoral systems. Developing a general theory on the relations between identity politics, democratisation, and state building is beyond the scope of this paper. Instead, the paper aims to contribute to our understanding of the nature of the relationships by exploring how they have unfolded in Ethiopia's fifteen-year-old federal arrangement.

* Dr Kidane Mengisteab is Professor of African Studies and Political Science in the Department of African and African-American Studies at the Pennsylvania State University, University Park, Pennsylvania. 


\section{Introduction}

Relationships between identity politics, democratisation, and state building constitute a complex analytical terrain in African realities. Part of the complexity emanates from the fact that in relatively new states, such as those in Sub-Saharan Africa, national citizenship and ethno-national citizenship are often in competition, if not in conflict. In addition, the relationships between the three variables are mediated by the interplay of a number of other factors, including the nature of the historical state-identity and inter-identity relations; the nature of the state, including the quality of its leadership and its effectiveness in promoting the well-being of its citizens equitably; the state's approach to state building; the organisation of political parties and the structure of electoral systems.

As a case study, this paper does not aspire to develop a general explanation of the relationships between identity politics, democratisation, and state building. Its rather modest objective is to contribute to our understanding of the nature of these relationships by exploring how they have unfolded in Ethiopia's fifteen-year-old federal arrangement, which has been instituted with the stated objectives of enhancing state building and democratic governance by granting identity groups the right of selfgovernance.

The paper is organised into five parts. The first outlines tentative propositions that intimate how the mediating factors identified above impact the relationships between identity relations, democratisation, and state building. It also attempts to clarify the concepts utilised in the propositions. The second part discusses the rationale for the institution and composition of Ethiopia's federal arrangement. The third part discusses how a federal arrangement facilitates state-building. The fourth part examines the basis for the sceptical reaction to the arrangement by many political organisations and appraises the performance of the federal arrangement in resolving identity-based conflicts in the country. The fifth part synthesises some of the key factors that have hampered 
the federal arrangement from transforming identity relations and registering significant advances in the processes of democratisation and state building.

\section{Factors affecting the nature of identity relations}

It is likely that the interaction between the state and identity groups and among identity groups would be more susceptible to conflict in countries where state building and consolidation of national citizenship are less developed, inter-identity relations are unequal and the state is perceived to be partial in its relations with identity groups. In such countries ethnonationalism would be a strong mobilising force of the population, since it is not counter-balanced or mitigated by developed intra-group socioeconomic differentiation, inter-group socio-economic ties, and national citizenship. Moreover, where identity politicisation and mobilisation are high, political parties are likely to be organised largely along ethnic lines. Under such conditions crafting a political system that accommodates the interests and demands of competing ethnic groups becomes highly challenging, especially where some forms of proportional representation and consociational decision-making systems are not in place, as Lijphart (1999) and Cho (2007) note.

Historically, the initial stages of state building were accomplished mostly through expansionist conquests or reactions to such efforts. Referring to nineteenth-century Europe, Lewis Namier notes that, 'states are not created or destroyed, and frontiers redrawn or obliterated, by arguments and majority votes; nations are freed, united, or broken by blood and iron, and not by a generous application of liberty' (Schwarz 1995:60). Charles Tilly (1975) also confirms that European states emerged as a consequence of wars. It seems that ethnic identity was rarely a major consideration in state making since most states are multi-ethnic. State building or consolidation, which follows the initial crafting of a country, is, however, achieved through various peaceful mechanisms, including economic integration, democratisation, and socialisation. 
The initial carving of states is often the result of either internal expansion or external colonial conquest. The Ethiopian case would suggest that state consolidation is not impacted differentially by the two processes. The modern Ethiopian state was created through expansionist conquests in the second half of the $19^{\text {th }}$ century and the state-building problems the country currently faces are not any less challenging than those faced by most other African countries, which were carved out by European colonialism. Even if the differences are not inconsequential, what matters most seems to be whether or not the state develops the peaceful state consolidation mechanisms to integrate the populations under its domain into a political community of national citizens.

The colonial state had no interest in promoting state consolidation mechanisms in its colonies, which were essentially territories for monopolised plunder. In most cases, the post-colonial African state also has yet to develop such mechanisms. Often African states revert to coercive measures when challenged by identity groups. The results of the coercive approach have been dismal, however. The state in much of Africa lacks the military capability to quell quickly the armed challenges it faces from identity groups. Many African civil wars thus linger for a long time, as the examples of Somalia, the Sudan, Uganda, the Democratic Republic of the Congo (DRC), and the Ivory Coast demonstrate. Even when the violent conflict is brought to a conclusion through a military victory of one side or another, military success rarely translates into a permanent peace and successful state building without the appropriate mechanisms for consolidation of national citizenship. Several African countries, which were able to end their civil wars through military means, including Nigeria, Ethiopia, Uganda, Rwanda, Angola, the DRC, the Republic of Congo, and Chad, remain embroiled in new conflicts or continue to face growing ethnic and civil strife (Mengisteab 2004). As Collier et al (2003) note, the economic destruction and disruption that accompany lingering civil wars also make future conflicts more likely by intensifying economic hardships and hatred. 
In the present era, where human rights and democracy have been widely accepted as universal values, violent and coercive measures have also increasingly lost legitimacy. Countries that forcefully subjugate their citizens in the contemporary global realities often face condemnation by humanitarian organisations, the United Nations (UN) system, and other members of the global community, as demonstrated by the Darfur case in the Sudan. Okafor (2000:525) makes a compelling case when he asserts that '.. . violent, coercive unification and repressive homogenization are morally and socially bankrupt.' State building in the present era has increasingly become intertwined with building a democratic system that allows the crafting of political arrangements that accommodate the various identities. Existing identity-based conflicts, however, often make the democratisation process more difficult.

The nature of the state is another factor with major impact on the relationship between identity politics, state building, and democratisation. If the state is perceived to be an effective agent for the advancement of broad social interests in an equitable and just manner, then the prospects are greater that the interaction between the state and identities as well as among identities would be more peaceful. By contrast, the state is likely to face challenges from ethnic identities if some groups perceive it to be incapable of advancing broad social interests or view it as partial to particular identities.

The nature of identity relations, in turn, is likely to impact the nature of the state. The more identity politics are characterised by state-identity or inter-identity hostilities, the more difficult it will become for the state to provide public goods and services effectively or to establish itself as a neutral promoter of broad social interests. It is also more difficult for the national elite to overcome the temptations of ethnic loyalties in favour of national goals.

The nature of the post-colonial state in Africa remains highly problematic. The state is widely viewed as a self-serving apparatus that is often dominated by one identity group or another and manipulated by external 
actors. As a result, many African countries are caught up in a vicious cycle. They need an inclusive and democratic state which is committed to advancing broad social interests in order to reconcile identity relations and, thereby, promote state building. Such characteristics of the state are not attainable without reconstitution of the state and transformation of state-identity relations, however. In countries, such as Ethiopia, which are characterised by chronic crises of state building, manifested in the volatile state-identity relations and a state which is widely perceived to favour one identity group or another, breaking the vicious cycle and transforming identity relations is a daunting task. The combination of ethnic-based political parties and majority-based electoral systems adds to the complexity.

Before discussing the Ethiopian experience, however, it would be helpful to clarify the key concepts contained in the main thesis of the paper, including identity, state building, and state reconstitution. Most countries consist of populations with multiple identities - including those based on race, ethnicity, religion, territory, institutions and values. Such plurality often leads to diversity of interests and even differences in perspectives on various issues, such as political philosophy and economic and cultural policy. The diversity of interests and perspectives that emerge from the plurality of identities may not, in themselves, be a source of conflict if the liberal conception of citizenship in which the rights and obligations of individuals are well established and the institutions that guarantee such rights are firmly in place. Such conditions, however, rarely exist and, in their absence, individuals tend to rely on their ethnic membership for security, social support, and access to resources. Identity-based loyalties thus easily become a source of mobilisation when conflict over resources and power lead to antagonistic rivalries.

Distinctions are often drawn between ethnicity as a cultural identity - an identity based on shared cultural traits - and ethnicity as a political identity - where it becomes an organising force for purposes of advancing the group's broad socio-economic interests. It is not likely that cultural identities exist without some level of politicisation. In any case, this 
paper is mainly concerned with the political aspect of ethnicity where ethnic groups constitute an ethnic or civic citizenship and participate in two publics and authorities - the ethnic group and the state (Ekeh 1975; Sklar 1993; Ndegwa 1997). One reason for focusing on ethnicity as a political identity is that Ethiopia's federal system is crafted largely, although not exclusively, along ethno-linguistic lines and the country's constitution has formally institutionalised ethnic citizenship. A more general reason is that ethnicity in Ethiopia, as in many other African countries, is politicised and groups claiming to represent ethnic entities are major players in political conflicts.

For the purposes of this paper, state building is used in two interrelated conceptions. One is in lieu of nation building to avoid confusion between state and sub-state nationalisms. It refers to the complex process of forging national unity and integrating the various identities in a country to form a community of citizens (national citizenship) under shared political and economic systems. The second conception refers to developing institutions of the state to enhance the capacity and effectiveness of the state in advancing the well-being of citizens and in managing society in line with the authority mandated to it by citizens.

State reconstitution is another equivocal concept that requires clarification. Given the African colonial and neo-colonial experience, the post-independence African state has retained many of the characteristics of the colonial state and operates largely outside the control of its citizens and in isolation from the traditional institutions and cultural values of its constituency. As a result, it largely operates as a predatory apparatus and as a source and dispenser of privilege rather than as an apparatus that advances broad societal interests. In addition, its governance structures often run parallel to the traditional institutions of governance, which are still adhered to by large segments of the population, especially in rural areas. The economic systems of African countries are also fragmented between the modern and traditional sectors. The duality of economic systems and institutions of governance, along with the disjuncture between policy and broad social interests, made possible 
by the state's independence from societal control, have all contributed to the incoherence of African governance institutions, thereby, undermining state building, economic development, and democratisation. In addition to these general characteristics of the African state, the Ethiopian state, which was created through expansionist conquests, has its own particular characteristics. The state, at least until the mid 1970s, largely maintained close political and cultural ties with the (Abyssinian) identities that created the modern state through conquests, relegating the subjugated identities into second class citizens by marginalising them from political power and cultural influence.

State reconstitution is utilised to refer to two types of changes. One is to bring synergy in state-society relations by bringing the state under the control of the citizenry, thereby transforming it into an agent for the advancement of broad social interests. The second and related conception refers to state neutrality. Since a major aspect of politics deals with the allocation of access to resources, including political power, various identities in the pursuit of maximising their access to power, resources, and other opportunities, engage in competition. But they are also likely to cooperate in order to advance mutual interests and to prevent one identity from establishing a hegemonic domination over all others. Such competition and cooperation, however, take place within the socio-economic platform established by the state. If the state lacks the necessary level of neutrality for the fair management of identity relations and moderation of inter-identity inequalities, then identities are likely to engage in violent conflicts often against the state but sometimes directly against each other. As noted, such conflicts, of course, hinder democratisation, and the absence of democratic governance, in turn, hampers state neutrality and state building - producing a vicious cycle.

State neutrality may not be fully attainable in multi-ethnic countries, as some languages and cultures are likely to be more dominant than others. A democratic system of governance with equitable representation of all groups can, however, reduce biases. Decentralising governance structures 
and building institutions that ensure separation of powers among the various organs of the state also mitigate biases.

\section{Rationale for the ethnic-based federal arrangement in Ethiopia}

Between the early 1960s and the beginning of the 1990s the Ethiopian state faced a costly war against Eritrean nationalists, who opposed Ethiopia's annexation of their country by abrogating the UN-instituted federation between the two entities. Along with continued economic stagnation, the country also faced growing revolts by ethnic identities, who opposed what they considered to be a highly centralised system of governance that marginalised their socio-economic and cultural rights and suppressed their self-determination (Worku Lakew 1992; Gebru Tareke 1991). Such revolts were particularly rife among ethnic identities in the southern and eastern parts of the country which were incorporated into the Ethiopian empire through expansionist conquests, during the last two decades of the $19^{\text {th }}$ century. With the empire's expansionist conquests, ethnic relations evolved into a political, economic, and cultural subordination of the newly incorporated identities, who in many cases were reduced to landless tenants, while many of the occupying troops and administrators emerged as landlords. Following the country's incorporation into the global economy, beginning in the early 1950s, Ethiopia's political economy also evolved into uneven regional relations. With the centre of the empire and centre of modern economic activity located in Addis Ababa and its surroundings, even parts of the former core of the empire, Tigray in particular, were reduced to peripheral status.

As resistance by the subordinated and marginalised identities escalated in the 1960s and the country drifted into deepening turmoil, the rights of 'oppressed' nations and nationalities, along with land reform to restore land to the tillers, became key issues of debate and demands by the University Students' Union of Addis Ababa (USUAA) and other progressive elements in the country. The frequent protests by USUAA, 
and its publication, Struggle, played important roles in articulating the critical problems facing the country at the time and in inciting opposition to the monarchy which was overthrown in 1974 by a military junta. The country's intelligentsia across the ethnic spectrum, including the leaders of the Tigray People's Liberation Front (TPLF), many of whom attended Addis Ababa University, was influenced by USUAA's debates and demands. USUAA's views on the right of nations to self-determination lacked a concrete conceptualisation of the specific governance structures that would actualise the right of self-determination of nations and whether self-determination included secession. At least one article in Struggle argued, however, that secession, in principle, is the right of an oppressed nation (Wallelign Mekonnan 1969). The federal arrangement instituted by the Ethiopian People's Revolutionary Democratic Front (EPRDF) in 1991 is thus largely a response to the widely recognised discontent of various ethnic identities in the country with the centralised and oppressive governance structure. It also has an ideological basis that can be traced back to the movement of the country's university students of the 1960s and 1970s.

The federal arrangement also reflected political pragmatism on the part of the EPRDF leadership. The country was verging on disintegration along ethnic lines, as manifested in the multiplicity of ethnic-based liberation movements. At the time it was unlikely that the TPLF and its coalition partners would succeed in replacing the collapsed military regime in power and rule the country without addressing the demands of the identity-based political organisations. When the regime of Mengistu Haile Mariam fell, the TPLF and the Oromo Liberation Front (OLF) along with various groups, which represented or claimed to represent 'oppressed' or 'marginalised' ethnic identities, were opposed to a centralised unitary structure of the state. Whether the federal arrangement was a top-down imposition or a broad-based pact among the elite of the various ethnic identities is, however, debatable.

As Aalen (2002:2) notes, the federal arrangement can be viewed as an arrangement resulting from an understanding among the identity-based 
organisations that participated in the July 1991 National Conference. The Conference, which was attended by some twelve political groups with roughly 400 delegates, adopted a provisional Charter, approved the establishment of a transitional government led by the EPRDF, and recognised the right of nations to self-determination - including selfgovernance, cultural autonomy and even secession. An 87-seat Council of Representatives (CoR) was also established to implement the Charter. The CoR appointed a Constitutional Drafting Committee and the new constitution, which was ratified on December 8, 1994, confirmed the right of identities to secession.

Although ethnic groups were invited to send representatives to the National Conference (Said 1998), participation was not open to all political organisations that existed at the time. Merera Gudina (2004), for example, contends that the EPRDF leaders invited weak parties and excluded potential contenders for power from the process. Two non-ethnic-based political organisations, the All Ethiopia Socialist Movement (MEISON) and the Ethiopian People's Revolutionary Party (EPRP), which were opposed to the ethno-nationalist movements, were, for example, excluded from participation. Groups that are now opposed to the constitutional provision that grants the right of secession to ethnic groups also claim lack of adequate representation in the constitutionmaking process.

Another factor that hindered the process from being a genuine pact among all relevant entities was the uneven power relations among the groups that participated in the National Conference. The TPLF (and its coalition members within the EPRDF) was the most powerful actor followed by the OLF, while other groups were far weaker both militarily and politically. Such imbalance in power relations created at least the perception that the arrangement was authored and imposed by an understanding between the two more powerful organisations.

The nature of the TPLF was another factor. As an ethnic-based movement, the TPLF pushed for a federal arrangement with the right of 
secession. As a movement that came to control central power through military means with little support from other identity groups, however, it was less than keen to share power with other regional actors and thereby promote genuine self-rule. The TPLF's rocky relationship with the OLF, which resulted in the destruction of the latter militarily, is a case in point. The federal arrangement can thus hardly be regarded as a national consensus that resulted from a democratic interaction among the country's various political organisations. It is, however, difficult to argue that it was destined to fail, since democratic governance, which develops trust among the various actors, was still possible, despite the initial missteps.

The foregoing discussion also explains why Ethiopia's federal arrangement was crafted largely along ethno-linguistic lines. The regional states, except the two chartered cities, Addis Ababa and Dire Dawa, and the regional state of the Southern Nations, Nationalities and People's, which are multi-ethnic, are carved along ethno-linguistic lines. Demarcation of the regions along ethnic lines, no doubt, was rather complex due to the historical demographic movements and intermingling of identities. The key players in the negotiation process at the National Conference were, however, ethno-nationalist groups and their demands were ethnicbased. The outcome was thus predetermined by the nature of ethnic relations in the country and by the composition of the key political players at the National Conference. Ethiopia is hardly an exception in this regard, however, since many successful federal arrangements in the world, including those of Switzerland, Belgium, Canada and Malaysia, are constituted along ethno-linguistic lines.

\section{Identity relations and state building under the federal arrangement}

There are various conceptions of federalism. For most students in the field, it represents a political system in which a constitutionally guaranteed division of jurisdictions and functions between central and geographically defined regional governments precludes the total subordination of 
one to the other (Riker 1964; Watts 1966; Elazar 1976; Lijphart 1979; Osaghae 2004). For others, it represents a relative difference in the degree of decentralisation of political power along a continuum rather than a different kind of political system (Livingston 1952). Despite the conceptual differences, a federal arrangement is widely regarded to have greater potential than a unitary governance structure in mitigating conflicts in countries where society is constituted of '... territorially based communities that are clearly differentiated by language and ethnicity...' (Stein 1968:729). This potential emanates largely from the fact that it represents a constitutionally guaranteed 'covenant or compact' between the state and regional entities about how power is shared between them, thereby creating various centres of power through regional self-rule. Since the nature of the covenants, which combine regional 'self-rule' and central 'shared rule,' may differ in various countries, federal arrangements may also differ from one case to another.

In reality, federal arrangements do not always result from a negotiated pact between the central government's elite and its regional counterparts. Two other conditions can lead to the establishment of a federal arrangement, although these conditions tend to undermine the arrangement's effectiveness. One is the conviction of or calculation by leaders of the central government that some dispersal of power that addresses the demands of identity groups for group rights and self-rule might mitigate identity-based conflicts and facilitate state building. The central elite may also see the arrangement as a mechanism for consolidating its grip on power, especially if it can divide and weaken regionally based opposition or demands for self-rule. In any event, the arrangement, in this case, is largely authored by and imposed from the top - often without the consent of the regional elite or with the support of only a segment of the regional elite.

Another condition that can lead to the institution of a federal arrangement is a negotiated agreement or understanding among the leaders of various identities when the central government has collapsed, as in Ethiopia. In this case also, the arrangement and its terms may or may not 
have the consent of all relevant parties. Consensus among the relevant parties on the terms of the arrangement is, however, a requisite for the success of a federal system. As Elazar (1976) notes, a government that decentralises power can also recentralise it.

The different parties to a federal arrangement have different expectations and they also have different criteria for success. The central government's expectations largely revolve around the avoidance of violent conflicts and the promotion of national unity (McHenry 1997). From the point of view of each of the ethno-nationalist claimants, however, success entails enhancing the group's interests, including autonomy in local governance and freedom to develop its own culture and economy. A successful federal arrangement would have to satisfy the key interests of the state and those of the divergent groups, not only in terms of outcomes but also in terms of the process in creating the arrangement and establishing its terms. With respect to the process, a federal arrangement requires certain preconditions - including a national consensus on preservation of national integration under negotiated terms and access of all political organisations, especially those with identity-based demands, to participate in the negotiation process to establish the arrangement.

Consensus on national integration is critical for the success of a federal arrangement, since identities not interested in national integration are unlikely to participate in its establishment and attempts to impose it on such groups may undermine the arrangement as well as the whole process of state building. The Eritrean People's Liberation Front (EPLF), for instance, did not participate in the National Conference that established Ethiopia's federal arrangement and it was not possible for the Ethiopian state to impose the arrangement on Eritrea without re-igniting the thirty-year-old war against Eritrean nationalists.

The terms of the federal arrangement also need to be established through a general consensus. The arrangement would likely be undermined by spoilers if the process of establishing it is not inclusive or if the terms of the arrangement do not have the consent of the relevant actors. 
Exclusion of any entity from participation or imposing the terms of the arrangement on any entity over its objections amounts to denial of representation in the establishment of the political system that determines the process of state building and developing structures of governance.

In other words, to be successful, the establishment of a federal arrangement has to be conducted in a democratic or at least a consociational manner. The consociational requirement, however, implies that, if a pact cannot be reached, an option of exit from the state is available to identity groups that demand it. Needless to say, in addition to satisfying the preconditions, the government has to implement the arrangement properly so that the demands of ethnic identities or regional entities for self-rule and cultural autonomy are respected.

Given the identified criteria, Ethiopia's federal arrangement can be assessed by creating a composite index of indicators of success that would include the preconditions, the manner of implementation, and the outcomes. Such a list of indicators includes (1) a general consensus on national integration, (2) inclusiveness of the process of negotiation to establish the federal arrangement, (3) a general consensus on the contents of the federal arrangement among the participants, (4) dispersal of power among the federal constituents to ensure self-rule and cultural rights, and (5) avoidance of violent conflicts.

Since a key goal of a federal arrangement is to resolve state-identity and inter-identity conflicts and, thereby to foster state building and democratic governance, avoidance of violent conflicts over time can serve as a proxy for the proper institution, implementation, and functioning of a federal arrangement. The groups that rebelled against the highly centralised unitary structure of governance in Ethiopia prior to 1991, for example, can be expected to challenge the state again if their participation in the making of the federal arrangement was hindered, if they did not consent to its contents, or if implementation did not satisfy their demands. Identities that did not challenge the state under the previous regimes may also opt to do so if they feel bypassed in the establishment 
of the new arrangement by the current regime. To the extent that the various groups that were engaged in conflict prior to its institution consented to the federal arrangement, the level of violence in the country would be expected to decline. If the arrangement is not properly implemented, however, the violence may begin to increase as disillusionment with the arrangement sets in.

\section{Consensus on national integration}

Prior to 1991, there were several groups in the country that waged armed struggle for independence (see Table 1). None of these groups have officially renounced their independence goals. Yet, the demand for independence has sharply declined, at least in intensity, in the post-1991 era. The TPLF had a long standing bifurcated strategy of creating a united democratic Ethiopia or an independent Tigray. The alternative goal of independent Tigray has become mute since the TPLF assumed state power. Like the TPLF, the OLF also pursues the goal of independence of Oromia without rejecting national integration under terms it favours. Its participation in the 1991 National Conference as well as in the early phase of the Transitional Government, between 1991 and 1992, reveals the flexibility of its stand on independence. Even after its withdrawal from the Transitional Government and its resumption of armed struggle, the position of the OLF does not seem to have changed. The Ogaden issue is more difficult to read as it is complicated by the (Greater) Somali nationalism and irredentism. It also constitutes one of the most serious tests of the constitutional provision that grants the right to secession. The magnitude of the violence in the Ogaden, however, reveals that the right of secession that the constitution grants is merely nominal. Nevertheless, although failure to facilitate regional self-rule might rekindle them, demands for independence outside of the Ogaden are much less intense now than they were in the pre-1991 era. However, a strong consensus on national integration has yet to emerge, however. 


\section{Reaction to the federal arrangement}

As noted, the terms of the federal arrangement were more the product of an understanding between the more powerful organisations, the TPLF and the OLF, than a consensus among all identities. Partly as a result of the lack of inclusiveness of the process, Ethiopia's federal arrangement has remained controversial among many of the country's political parties. In any case, since most of the political parties are organised along ethnic lines, their reaction to the arrangement can serve as proxy to reaction by ethnic identities. It is important to note, however, that the political parties in the country and the inter-party coalitions, that are being established, are still in a formative stage and, as a result, the positions they hold on various issues, including the federal arrangement, are still evolving. Nevertheless, at least four competing views on the federal arrangement can be identified.

One view strongly opposes the federal arrangement in favour of a unitary political structure. This view, which is largely expressed by Amhara-based parties, such as the All Amhara People's Organisation (AAPO), is particularly opposed to the constitutional provision that acknowledges the right of ethnic identities to secede. According to this view, recognising the right of secession is a prelude to the country's disintegration. Some observers also see the federal arrangement 'as a path bound to lead either to increased repression or to mounting ethnic conflict and eventual disintegration of the country' (Ottaway 1994:47). A major campaign issue of the opposition parties within the Coalition for Unity and Democracy (CUD) during the May 2005 national election was to change the constitutional provision that grants ethnic groups the right to secede.

Another view accepts the federal arrangement in principle but opposes that it is ethnic-based and that it grants ethnic entities the right of secession. This view is expressed by various opposition political organisations, especially in the Southern Nations, Nationalities and Peoples' Regional State (SNNPRS). Parties, such as the Ethiopian Democratic Party (EDP) also subscribe to this view. 
A third view, predominant among Oromo opposition parties and organisations, including the OLF and the Oromo Federalist Party (OFP), accepts the ethnic-based federal arrangement and the right of secession granted to ethnic identities. It contends, however, that the arrangement is totally undermined by the government's unwillingness to disperse power. According to this view, Ethiopia's political system remains highly centralised and dominated by a single ethnic identity and the government uses the arrangement for purposes of divide and rule rather than for fostering self-rule by regional governments.

A fourth view, advanced by the ruling coalition and its affiliated parties contends that the arrangement has vested the right of self-determination upon ethnic identities and has charted a voluntary and democratic approach to state building.

Many of the political organisations critical of the federal arrangement were not in existence at the time of its formation. Nevertheless, the divergence in views reflects the democratic deficit that characterised the establishment of the arrangement.

\section{Cultural rights, dispersal of power, and self-rule}

Notable progress has been registered in advancing the cultural rights of formerly suppressed identity groups since the institution of the federal arrangement. Identities, such as the Oromo, whose language could not be used in public settings during the era of the monarchy, are now able to develop their cultures and to use their languages in broadcasting through various media outlets. There is also greater recognition of religious rights. Moslem communities in the country, for instance, are now freer to build mosques and to celebrate their holidays. Such changes were initiated during the military regime but they have been advanced further under the EPRDF government. No doubt, many challenges still remain. There is, for instance, the difficult task of reconciling the different perspectives among identities on historical memories, as some historic events and personalities trigger ethno-nationalism among some 
identities and nationalism among others. Some of the builders of the modern Ethiopian state, such as Emperor Menelik II, for example, are viewed as heroes by some identities while others view them as brutal colonisers, who engaged in slave trade and condemned their victims to poverty through devastating plunder and land expropriation.

Some progress has also been achieved in the realm of self-governance. The need to address the problem of identities is now widely recognised. Regional governments have thus been established with the federal arrangement, although a great deal of disagreement persists about the composition of the regional units. Progress with respect to empowering the regional states to conduct self-rule independently from the central state remains less visible. The absence of inclusive dialogue and general consensus on the establishment of the federal arrangement among the elite of various identities was one major factor that has obstructed progress. This democratic (consociational) deficit has hindered the development of trust and confidence between the government and the various identity-based opposition groups.

Ethiopia is a country with some 80 ethnic identities (Institute for the Study of Ethiopian Nationalities 1985). Three identities, the Oromo, Amhara, and Tigray, are, however, the most predominant, and success of the federal arrangement and the country's political stability are likely to, largely but not exclusively, hinge on the configuration of power among the elites of these three identities.

The Tigray identity is the smallest of the three in population size. It was also politically and economically marginalised following the abrupt end of the reign of Emperor Yoyannes IV in 1898 and the shift of power to the Amhara of Showa. In 1991, however, the TPLF overthrew the military regime, in association with the Eritrean People's Liberation Front, and assumed state power in conjunction with two smaller organisations; the Oromo People's Democratic Organisation (OPDO) and the Amhara National Democratic Movement (ANDM). The TPLF created the OPDO and ANDM before it assumed power to form the Ethiopian People's 
Revolutionary Democratic Front (EPRDF) in an attempt to broaden its popular base beyond Tigray by providing representation in the front to the Oromo and Amhara identities respectively. The two organisations, however, have found it rather difficult to win legitimacy from their respective identities, at least in part due to the fact that they were created by the TPLF and not independently formed or home-grown. The OLF in particular resented the creation of the OPDO, which it views as a puppet organisation designed to serve Tigrean hegemony (Chanie 1998). While the reaction in rural areas is difficult to determine, the EPRDF's assumption of power was received with widespread scepticism and resentment by the urban population and political organisations in much of the country outside Tigray.

The Amhara comprise the second largest group in the country and the political elite came largely from this identity group during the period between the late $19^{\text {th }}$ century and at least the fall of the monarchy in 1974 (Clapham 1969). In the early 1970s, for example, about $65 \%$ of officers at the rank of lieutenant-colonel and above were Amhara, whereas 20\% were Oromo. Even in the late 1970 s roughly $50 \%$ of the officer corps was Amhara. In part due to their greater access to education, the Amhara are also said to have continued to dominate the bureaucracy, even after the fall of the military regime (Young 1996). Given the dominant role the Amhara elite played in Ethiopian politics, at least since the late $19^{\text {th }}$ century, their displacement by a new Tigrean elite in the top echelons of power has hardly been palatable to the Amhara elite (Henze 1998). While the dominant role of the Tigrean elite in the regime brought about convergence between national and Tigrean citizenships, it brought about divergence between national and Amhara citizenships, triggering the rise of Amhara ethno-nationalism (Tegegne Teka 1998). The TPLF's recognition of Eritrean independence, which left Ethiopia landlocked, also gave critics of the new regime the ammunition for questioning TPLF's patriotism. For these critics, the federal arrangement is essentially a TPLF scheme to divide the country along ethnic lines in order to facilitate the 
extension of its control of power (Interviews with leaders of political parties, 2006; Walle Engedayehu 1993).

The Oromo constitute the single largest ethnic group in the country and are said to comprise roughly $40 \%$ of the country's total population. The Oromo masses were largely reduced to landless tenants after their incorporation into the empire through conquest during the waning decades of the $19^{\text {th }}$ century. The country's major exports, including coffee, largely come from Oromo areas. While the 1975 land reform liberated the Oromo masses from tenancy, the OLF and other Oromo militants contend that the Oromo still remain under domination, as they are underrepresented in the central power and the self-rule promised by the federal arrangement remains essentially nominal (Leenco Latta 1998). National citizenship and Oromo citizenship thus remain divergent under the current regime, as they did during the previous two regimes. The OLF is still operating as an armed rebel movement. It has, however, not yet been able to mount a serious military threat to the regime.

Given the widespread resentment of the EPRDF's takeover of state power and the absence of a national consensus in the creation of the federal arrangement, the rivalries and mistrust among the political elite of the different identity groups, especially among those of the three largest groups, have continued. Despite its control of the military, the TPLF has a distinct disadvantage and a dilemma in the inter-identity rivalry. The disadvantage is that, to the extent that ethnic affiliation remains an important factor in how people vote in elections, the TPLF, with a small population base of roughly $10 \%$ of the country's total population, can hardly be expected to maintain central power by winning elections that are conducted fairly. The dilemma is that perhaps it can extend its control of power through coercive means relying on the military but this makes it indistinguishable from the dictatorial regime it replaced and harms its relations with the donor community by spoiling the democratic image it attempts to project. 
The TPLF seems to have devised a three-pronged strategy to deal with the disadvantage and the dilemma it faces. One aspect of the strategy has been to expand the circle of its coalition and affiliated parties by creating or attracting ethnic-based organisations throughout the country and win elections as a bloc. This aspect of the strategy, however, has created its own set of dilemmas. On the one hand, in order to win legitimacy among their constituents, which is essential for electoral success, its coalition partners and affiliates need to assert their independence from the TPLF. If these parties attain independence, however, there is the potential risk to the TPLF that the OPDO and ANDM, in particular, can overshadow it, due to their larger demographic base. On the other hand, if they fail to assert their independence these parties risk failing to gain legitimacy among their constituency, thereby undermining their chances of electoral success, without which their relevance to the TPLF also diminishes.

A second aspect of the strategy seems for the TPLF to rely on the application of decisive force against rebel groups and even opposition parties that pose threat to its regime, using the pretext of keeping order. The manner in which the government reacted to the protests following the announcement of the results of the May 2005 parliamentary elections seems to validate the existence of such a strategy. The protests resulted in the deaths of 193 people (BBC News 26 October 2006). It is, of course, possible that the deaths could have been due to spontaneous overreaction by the police forces. However, it is likely that the severity of the government's reaction was intended to send a message to opponents, since it was followed by the detention of some 76 opposition politicians, journalists, and civil society activists under charges that include 'treason and genocide', which are non-bailable capital offences (Human Rights Watch 2006). Repressive measures against suspected sympathisers of armed rebel groups, such as the OLF is another indication (Amnesty International 2006).

A third component of the strategy is to gain international legitimacy by establishing close relations with powers, especially the United States (US). 
The regime's willingness to partner with the US in the 'war against terrorism' in Somalia has, for instance, gained the regime political and financial support. None of the aspects of the strategy, however, advance the self-rule that the federal arrangement is expected to promote.

The centralising impact of the dominant party created through coalition building has also impeded progress in promoting regional self-rule. Opposition parties and critics widely view the coalition partners and the affiliated parties of the TPLF as satellite organisations created and manipulated by the TPLF in order to camouflage its highly centralised control of power (interviews of party leaders). They contend that the satellite parties lack popular legitimacy to win elections. The dominant role of the TPLF within the coalition, along with the absence of overt policy diversity within the parties in the coalition, suggests that the autonomy of the coalition members and affiliated parties may be rather limited. Regardless, the EPRDF with its partners has become a dominant party and was able to win elections rather easily and to control power both at the centre as well as at the regional governments until the 2005 elections although the fairness of the elections it conducted since it assumed power is highly questioned (Merera Gudina 2004). Its success was largely due to disorganisation and fragmentation of opposition parties, which often boycotted elections alleging unfairness of the electoral process. The unexpected results of the May 2005 national election have, no doubt, shaken the EPRDF's dominance sustained for over a decade. The party lost all 23 parliamentary seats in the capital city, Addis Ababa; although overall it took 327 of 546 total seats. But the opposition claims that the government stole the election it had lost by manipulating the results.

Even with the humbling setback, the ruling coalition remains dominant and exercises tight control of policy both at the centre and at the regions. At the regional level, despite its loss in Addis Ababa in the 2005 elections, the EPRDF controls the most important regions, including Oromia, Amhara, the Southern Nations, Nationalities and People's, and Tigray. Its affiliated parties also control the other five regional governments. The centralised party structure along with control of power in 
the regional governments has weakened the regional self-rule. According to some opposition party leaders, interviewed for this study, the governance structure in the country, for all practical purposes, remains as centralised as it was during the previous regimes.

\section{Avoidance of violent conflicts}

A crucial indicator of the performance of a federal arrangement is the extent to which it avoids or transforms violent conflicts. In this regard also, the arrangement has not been successful. The violence in the aftermath of the May 2005 election and the imprisonment of the leaders of opposition parties, along with the government's poor human rights record, especially in the Ogaden, indicate that the country remains deeply divided along ethnic lines. Regardless of their merits, the charges of genocide the government levelled against the leaders of the opposition also reveal that the federal arrangement has not transformed state-identity or even inter-identity relations in the country.

A growing number of identity-based armed movements have also reemerged. The magnitude of the wars waged by such groups has not reached the pre-1991 level, when the country seemed to be verging on disintegration. Since the withdrawal of the OLF from the transitional coalition government and especially over the past few years, however, armed conflicts in the country have been on the rise (see Table 1). In addition, a number of political parties seem to have grown more militant. In the aftermath of the May 2005 elections, a number of political organisations, including the Coalition for Unity and Democracy (CUD), All Amhara Peoples Organisation (AAPO), the Gambella Peoples Democratic Organisation (GPDO) and the United Ethiopian Democratic Forces (UEDF) have forged an alliance with the rebel movement, the Alliance for Freedom and Democracy (AFD). As noted, many of these parties are opposed to the federal arrangement. Even when they accept it in principle, many of them suggest conflicting criteria for establishing the component units of the federal arrangement including, geography, 
economic viability, size of territory and population, language, ethnicity, and culture. It is unclear, however, if the conflicts in Ethiopia are based on all the factors they suggest. In any case, given the current trend in the rise of armed groups, the institution of the federal arrangement can hardly be considered a success in reconciling state-identity conflicts and in advancing the processes of state building and democratisation.

Table 1: Comparison of the number of armed rebel groups before and after 1991

\begin{tabular}{|c|c|}
\hline 1960-1991 & Post-1991 \\
\hline 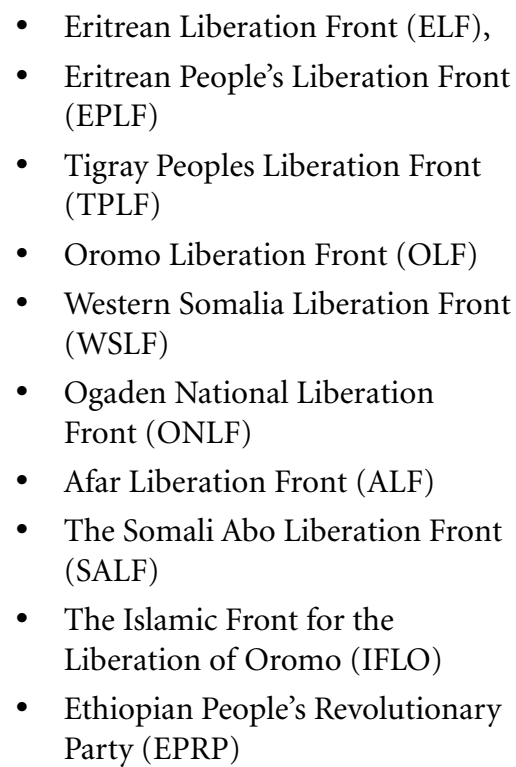 & $\begin{array}{ll}\text { - } & \text { Oromo Liberation Front (OLF) } \\
\text { - } & \text { Front (ONLF National Liberation } \\
\text { - } & \text { Dlliance for Freedom and } \\
\text { - } & \text { Sidamacracy (AFD) } \\
\text { - } & \text { Ethiopian People's Patriotic } \\
& \text { Liberation Front (EPPLF) } \\
\text { - } & \text { Afar Revolutionary Democratic } \\
& \text { Union Front (ARDUF) } \\
\text { - } & \text { Afar Liberation Front (ALF) } \\
\text { - } & \text { Gambella Liberation Front } \\
& \text { (GLF) }\end{array}$ \\
\hline
\end{tabular}

\section{Conclusion}

A number of factors have contributed to hindering the federal arrangement from attaining its stated goals. Lack of inclusiveness in the process of its formation and the resulting absence of a general consensus on its terms are among the critical factors. Failure to implement it properly by 
dispersing power is another factor. A genuine dispersal of power signals the emergence of a consociational system among the elite and between the centre and the regional governments that represent the various identities. Such a system had the potential to reduce the occurrence of violent conflicts, thereby facilitating state building and democratisation. In addition, a dispersal of power elevates the significance of power in the regions and leads to competition for power within the elite of the regional states. Such competition, in turn, can facilitate the emergence of organic national parties through formation of coalitions and unifications of parties with similar platforms across regions and ethnic identities.

Differences in capabilities between the centre and the regional governments may have contributed to the failure in dispersing power. A federal arrangement, as a constitutionally guaranteed political structure of noncentralisation, requires a certain balance of power between the central and regional elite so that the centralising tendency of the elite that controls state power is restrained. Without narrowing the gap in balance of power, the central elite's decision to formally adopt a federal structure does not necessarily indicate the elite's commitment to non-centralisation of power, as Enloe (1977) aptly notes. The different regions face a notable imbalance in capabilities that impedes implementation of extensive decentralisation.

Another major factor, which perhaps is an inherent structural weakness of the federal system, is how national parties, that encompass all or most of the ethnic identities, emerge out of the fragmented identity-based regional entities and parties. The Ethiopian experience, where the TPLF has created parties from other identities and forged a coalition under its wings, has resulted in hierarchical relations within the coalition. It remains to be seen if over time the EPRDF coalition will be transformed into a genuine national party with horizontal relations among its coalition members from different identities. At the present time, however, the EPRDF is largely viewed (at least by the opposition groups) as essentially a TPLF party with satellite parties as coalition members. As a result, 
many of the opposition organisations view the federal arrangement rather cynically as a strategy crafted to extend the minority TPLF government's tenure in power. Yet, the opposition parties have also not been able to forge a national party. The CUD, which was the major contender in the May 2005 elections, for instance, is largely viewed as a coalition of Amhara parties with merely symbolic representation of other identities. It is hardly more inclusive than the EPRDF and it is highly unlikely that a party dominated by a particular identity would gain legitimacy among other identities. Moreover, its opposition to the federal arrangement is unlikely to be acceptable to other identities, which demand self-governance with extensive decentralisation.

Another obstacle to the success of the federal arrangement has been the centralising nature of a dominant party. National parties are inherently centralising, as they formulate policy platforms for the whole country. They may even be more centralising when relations among the various identities are hierarchical. The building of coalition partners from various identities by the EPRDF, for purposes of creating a national party has thus become a mechanism that compromises the goals of decentralisation of power and promotion of self-governance for regional and identity groups. The opposition parties have also not been able to propose a political formula that addresses such problems. These organisations have yet to formulate and propose a credible alternative structure of governance capable of fostering state building. The primary goal of these organisations, thus far, has been to dislodge the ruling party from power and trade places with it. From its continued centralisation of power and the flawed successive elections it has conducted (Merera Gudina, 2004; European Union Election Observation Mission 2005), the EPRDF, on its part, appears to have little inclination to share power.

Developing healthy identity relations, democratisation, and state building are intricately interrelated processes. Failure in one area leads to failure in all. Moreover, the specific factors that have undermined the federal arrangement in Ethiopia cumulatively reveal that the developing healthy 
identity relations, democratisation, and state building require transformation of the elite, both those in power and those in opposition, and reconstitution of the state. Unfortunately, neither elite transformation nor state reconstitution has yet taken place in Ethiopia.

\section{Sources}

Aalen, L. 2002. Ethnic federalism in a dominant party State: The Ethiopian experience, 1991-2000. Development Studies and Human Rights Report. Bergen: Chr. Michelsen Institute.

Amnesty International USA 2006. Ethiopia: No progress on Human rights. Washington, D.C.: Amnesty International.

BBC News 2006. 'Scores Died' in Ethiopia Unrest. 26 Oct.

Chanie, P. 1998. The rise of politicized ethnicity among the Oromo in Ethiopia, in Mohamed Salih, M.A. \& Markakis, J. (eds), Ethnicity and the state in Eastern Africa, 95-107. Uppsala: Nordiska Afrikainstitutet.

Cho, W. 2007. Ethnic fractionalization, electoral institutions, and African's political attitudes. AfroBarometer Working Papers. Working Paper No. 66.

Clapham, C. 1969. Haile Selassie's Government. London: Longman.

Collier, P. et al 2003. Breaking the conflict trap. World Bank Policy Research Report. Washington, D.C.: World Bank \& Oxford University Press.

Ekeh, P.P. 1975. Colonialism and the two publics in Africa: A theoretical statement. Comparative Studies in Society and History 17 (1), 91-112.

Elazar, D.J. 1976. Federalism vs. decentralization: The drift from authenticity. Publius 6 (4), 9-19.

Engedayehu, W. 1993. Ethiopia: Democracy and the politics of democracy. Africa Today 40 (2), 29-52.

Enloe, C.H. 1977. Internal colonialism, federalism and alternative state development strategies. Publius 7 (4), 145-160.

European Union Election Observation Mission. 2005. Ethiopia: 2005: Final report on the legislative elections.

Gudina, M. 2004. Ethiopia: Constraints to transition and democratization, in Nhema, A. (ed), The quest for peace in Africa, 245-267. Addis Ababa: OSSREA.

Henze, P. 1998. Is Ethiopia democratic? A political success story. Journal of Democracy 9 (4), 40-54.

Human Rights Watch. 2007. Ethiopia: Events of 2006. World Report.

Institute for the Study of Ethiopian Nationalities. 1985. Achir ye-ethiopia behereseboch maweqiya (Brief introduction to the nationalities of Ethiopia). Addis Ababa: Institute for the Study of Ethiopian Nationalities. 
Lakew, W. 1992. Behind the News: Revolution in Ethiopia. Capital and Class No. 46 (Spring), 7-25.

Latta, L. 1998. The making and unmaking of Ethiopia's Transitional Charter, in Jalata, A. (ed), Oromo nationalism and the Ethiopian discourse, 51-77. Lawrenceville, NJ, and Asmara: the Red Sea Press.

Lijphart, A. 1979. Consociation and Federation: Conceptual and empirical links. Canadian Journal of Political Science 12 (3), 499-515.

Lijphart, A. 1999. Patterns of democracy. New Haven: Yale University Press.

Livingston, W.S. 1952. A note on the nature of federalism. Political Science Quarterly 67 (1), 81-95.

McHenry, D.E. 1997. Federalism in Africa: Is it a solution to or a cause of ethnic problems? Paper presented at the annual meeting of the African Studies Association in Columbus, Ohio.

Mekonnan, W. 1969. On the question of nationalities in Ethiopia. Struggle 5 (2), 4.

Mengisteab, K. 2004. Africa's intrastate conflicts: Relevance and limitations of diplomacy. African Issues 32 (1 \& 2, Fall), 25-39.

Ndegwa, N.S. 1997. Citizenship and ethnicity: An examination of two transition moments in Kenyan politics. The American Political Science Review 91 (3), 599-616.

Okafor, O.C. 2000. After martyrdom: International law, sub-state groups, and the construction of legitimate statehood in Africa. Harvard International Law Journal 41 (2), 503-528.

Osaghae, E. 2004. Federalism and the management of diversity in Africa. Identity, Culture and Politics 5 ( $1 \& 2), 162-178$.

Ottaway, M. 1994. Democratization and ethnic nationalism: African and Eastern European experiences. Washington, D.C.: Overseas Development Council.

Riker, W.H. 1964. Federalism: Origin, operation, significance. Boston: Little Brown.

Said, A. 1998. Afar ethnicity in Ethiopian politics, in Mohamed Salih, M.A. \& Markakis, J. (eds), Ethnicity and the state in Eastern Africa, 108-115. Uppsala: Nordiska Afrikainstitutet.

Schwarz, B. 1995. The diversity myth: America's leading export. The Atlantic Monthly 275 (5), 57-67.

Sklar, R. 1993. The African frontier of political science, in Bates, R., Mudimbe, V.Y. \& O’Barr, J. (eds), Africa and the Disciplines. Chicago: Chicago University Press.

Stein, M.B. 1968. Review: federal political systems and federal societies. World Politics 20 (4), 721-747.

Tareke, G. 1991. Ethiopia: Power and protest. Cambridge: Cambridge University Press.

Teka, T. 1998. Amhara ethnicity in the making, in Mohamed Salih, M.A. \& Markakis, J. (eds). Ethnicity and the State in Eastern Africa, 116-126. Uppsala: Nordiska Afrikainstitutet. 
Tilly, C. 1975. The formation of national states in Western Europe. Princeton: Princeton University Press.

Watts, R.L. 1966. New federations: Experiments in the Commonwealth. Oxford: Oxford University Press.

Young, J. 1996. Ethnicity and power in Ethiopia. Review of African Political Economy 23 (70), 531-542. 